ICIP WORKING PAPERS:

2009/8

Indigenous People's

Mobilization and their

Struggle for Rights

in Colombia

Farid Samir Benavides Vanegas

INTERNATIONAL

CATALAN

INSTITUTE

FOR PEACE 



\section{Indigenous People's Mobilization and their Struggle for Rights in Colombia}

Farid Samir Benavides Vanegas

Associate Researcher, PhD

Grupo COPAL

Universidad Nacional de Colombia

University of Massachusetts at Amherst

faridbenavides@gmail.com

This text is the English and short version of the text "Movimientos Indígenas y Luchas por los Derechos en Colombia”, also written for the Institut Catalá Internacional per la Pau. 
(C) 2009 Institut Català Internacional per la Pau

Gran Via, 658, baix. 08010 Barcelona (Spain)

T. +34 935544270 | F. +34 935544280

recerca.icip@gencat.cat |www.icip.cat

\section{Editors}

Javier Alcalde and Rafael Grasa

\section{Editorial Board}

Pablo Aguiar, Alfons Barceló, Catherine Charrett, Gema Collantes, Caterina Garcia, Abel Escribà, Vicenç Fisas, Tica Font, Antoni Pigrau, Xavier Pons, Alejandro Pozo, Mònica Sabata, Jaume Saura, Antoni Segura and Josep Maria Terricabras

\section{Graphic Designer}

Cla-se

\section{ISSN}

2013.5793 (on line edition)

2013.5785 (paper edition)

\section{DL}

B-38.039-2009 


\section{ABSTRACT (ENG)}

This text aims at showing the history of indigenous peoples' mobilization in Colombia, the effects that it has brought about on Colombian democracy and political system, and the state's reactions to their claims and actions. It will show how they have moved from class-based claims to a politics where identity claims have been central in their agenda and part of their strategies to negotiate with the state. It will also show the existing constitutional and legal framework that recognizes the rights of indigenous peoples, despite the context of persecution, murder, and forced displacement.

Keywords: Indigenous peoples; social movements; law; social mobilization in Colombia; strategic litigation.

\section{ABSTRACT (CAT)}

Aquest text mostra la història de la mobilització indígena a Colòmbia, els efectes que ha produït en la democràcia i en el sistema politic d'aquest país, així com la reacció de l'estat colombià als seus reclams i accions. Desitja mostrar com les organitzacions indígenes han passat de reclams basats en la classe social a una estratègia on els reclams basats en la identitat són centrals en la seva agenda i són part de la seva estratègia de negocació amb l'estat. També mostra el marc legal i constitucional que reconeix els drets dels pobles indígenes, malgrat el context de persecucions, assassinats i desplaçament forçats.

Paraules clau: Pobles indígenes; moviments socials; mobilització social a Colòmbia; dret; litigi estratègic.

\section{ABSTRACT (CAS)}

Este texto muestra la historia de la movilización indígena en Colombia, los efectos que ha producido en la democracia y en el sistema político de este país, así como la reacción del estado colombiano a sus reclamos y a sus acciones. 
Desea mostrar cómo las organizaciones indígenas han pasado de reclamos basados en la clase social a una estrategia en donde los reclamos basados en la identidad son centrales en su agenda y son parte de su estrategia de negociación con el estado. También muestra el marco legal y constitucional que reconoce los derechos de los pueblos indígenas, a pesar del contexto de persecuciones, asesinatos y desplazamiento forzado en su contra.

Palabras clave: Pueblos indígenas; movimientos sociales; movilización social en Colombia; derecho; litigio estratégico. 


\section{CONTENTS:}

\section{CONTENTS}

1. INTRODUCTION

2. WHY THERE AND THEN?

3. THE EMERGENCE OF INDIGENOUS MOBILIZATION IN LATIN AMERICA

4. THE EMERGENCE OF INDIGENOUS MOBILIZATION IN COLOMBIA

5. INDIGENOUS RESISTANCE

6. INDIGENOUS PEOPLES AND STRATEGIC LITIGATION

7. THE LIBERALIZATION OF RIGHTS

8. THE CONSOLIDATION OF RIGHTS

9. THE CONSERVATIVE COURT

10. CONCLUSION

11. REFERENCES 



\section{INTRODUCTION}

During the past six months, the Awá people, an indigenous people living in the south part of Colombia, has been victim of different acts of killing and persecution. Thirty-four members of the Awá people have been killed in 2009, and face the risk of being displaced and, even worse, of extermination. However, according to the Indigenous National Organization of Colombia ONIC, about 13725 members of the indigenous communities have been victims of different attacks. In the period 1996-2006 there has been an increase in the number of members of indigenous communities displaced from their lands. According to indigenous activists this is due to the model of neoliberal development that is imposed in Colombia and that seeks to establish extractive economies on indigenous territory (ONIC, 2009).

The violence exercised against indigenous peoples contrasts with the inclusive rhetoric that we find in Colombian 1991 Political Constitution. But the persecution against them is not new and is part of an old process of denial of difference in the country (Benavides, 2009). In 2004, the Special Rapporteur for the Rights of Indigenous Peoples Rodolfo Stavenhagen denounced what he deemed as an extremely delicate situation of indigenous peoples in Colombia. In 2008, current Special Rapporteur James Anaya made an in situ visit to the country and found and even worse situation: high rates of murders, increase in the numbers of persons being forcibly displaced, militarization of indigenous territories, repeated violation of indigenous peoples' right to be consulted, and development of megaprojects on indigenous areas, amongst others. The Special Rapporteur showed the negative effects that President Alvaro Uribe's policy of "democratic security" has on indigenous rights. Indigenous peoples are forcibly involved in the armed conflict and indigenous struggles for their rights are label as rebellion or terrorism and therefore Colombian judicial authorities prosecute indigenous leaders as if their exercise of rights was a grave crime (Anaya, 2009).

In spite of the fact of the persecution, or perhaps precisely because of it, Colombian indigenous movement is very well organized, with a strong political presence at the local and national level, with networks at all levels 
and with high visibility for their struggles and demands. According to some scholars, this is due to the fact of the existence of multicultural constitutions in Latin America (Van Cott, 2000), but this does not explain their long history of mobilization and their strong presence in national politics, at least during some time.

Social movements have been very present and active in Latin American politics. They fought agrarian reforms and labor laws during the 1960s; dictatorships and authoritarian rule during the 1970s; and neoliberal policies during the 1980s. However, it seemed that indigenous movements were nonexistent or invisible; their ethnic claims had to yield to class based claims, usually under the guidance of the traditional left. Given this panorama, there seems to be no explanation as to why there was an emergence of indigenous mobilizations in Latin America and why during the 1970 s and not before. One-cause explanations are too one sided and simplistic, and do not take into account the differences between indigenous mobilizations in Ecuador and Bolivia, with strong and very active movements, and struggles in Peru and Venezuela, where indigenous mobilization is recent and weak (Yashar, 2004). At the same time this kind of explanations cannot deal with the differences in strategies and symbols between Ecuadoran mobilization and the more media oriented but less effective Ejército Zapatista de Liberación Nacional EZLN. The 1980 s witnessed the emergence of a new kind of social mobilization, which has changed not only power relations in countries like Bolivia and Ecuador, but has even changed our old notions of citizenship, democracy, and the state.

In this text I aim at showing the history of indigenous peoples' mobilization in Colombia; the effects that it has brought about on Colombian democracy and political system; and the state's reactions to their claims and actions. I wish to show how they have moved from class-based claims to a politics where identity claims have been central in their agenda and part of their strategies to negotiate with the state. I will also show the existing constitutional and legal framework that recognizes the rights of indigenous peoples, despite the context of persecution, murder, and forced displacement. 


\section{WHY THERE AND THEN?}

The 1970 s were marked by the dominant presence of dictatorships in Latin America, up to a point that only two countries, Colombia and Venezuela, enjoyed at least some sort of formal democracy. A process of opening of the economies and the political systems was the distinctive mark of the 1980 s. Transitions to democracy and implementation of neoliberal reforms were seen throughout the region. But at the same time a process of reorganizing of social movements was under way. The emergence of the so-called new social movements can be traced back to the radical transformations affecting politics during the 1970 and 1980 s.

But under the deep disappointment with the traditional left and the guerrilla warfare, there was a process of indigenous mobilization that was getting stronger. Be it because of the transitions to more liberal democracies or to the fact of indigenous visibility; the truth is that Latin American constitutions were reformed and infused with a multicultural flair. The new constitutions included the right to the territory, the right to identity, and the right to autonomy (Alvarez \& Escobar, 1992). It seemed that there was a new social pact and a friendly liquidation of the past (Dugas, 1993; Van Cott, 2000). Yet it remains to be explained why centralist and racist elites decided to shift from assimilation and elimination to multicultural recognition (Laguado, 2004; Múnera, 2005).

The sudden and unexpected emergence of indigenous peoples was analyzed by social scientists. The literature on new social movements seek to give answer to questions like: Why in Latin America we see an indigenous identity- based mobilization? Why has it been so irregular in the whole region? Why some countries managed to write indigenous rights in their constitutions whereas others had to live with the traditional rhetoric? (Otero, 2003). In countries like Bolivia, Colombia and Ecuador, indigenous peoples act within a framework that allows them to claim constitutional rights, which gives their demands more weight and legitimacy. In spite of the traditional distrust in political parties, for their fragmentation and individualism, indigenous organizations created ethnic political parties, with 
different results in the region. In some cases, like Bolivia and Ecuador, their mobilization led to the presidency or to participation in the government; in others, like Colombia and Ecuador itself, to divisions and fights. Yet, the fact remains that indigenous peoples currently have more presence at the national level.

There are different explanations in the literature about the reasons why indigenous movements emerged in Latin America and at that particular time. These explanations go from essentialist analysis that assume that ethnic identification is enough to mobilize (Geertz and Stack, cited by Yashar, 2004); to institutionalist analysis, that assume that the difference between countries like Ecuador and Peru is due to the difference between institutions (Yashar, 2004). We also find explanations based on rational choice studies and analyses based on the idea that a global civil society is giving support to indigenous peoples and holding that this support explains their mobilization. Based on the idea of a global civil society, Bengoa (2000) and Brysk (2000) write that the lack of state's centrality in current international relations, the emergence of a global civil society around the idea of human rights and indigenous rights will suffice to explain the introduction of indigenous peoples' rights in some Latin American constitutions. To Brysk the weaker an indigenous organization is, the more likely to appeal to international solidarity. On the contrary, the stronger the organization is, the less likely to leave the local setting for its struggles. Brysk adds that it is more likely to appeal for international support at the earlier stages of the organizing process, because the group is weak and it has to face a very strong actor such as the state. In the phase of implementation of norms, Brysk finds that international support becomes unnecessary and for that reason the struggle remains local (Brysk, 2007).

Indigenous peoples have developed several networks to support their struggle. These networks have the task of protecting indigenous peoples and indigenous organizations from attacks coming from the state. At the same time in the last years some other networks have been organized in order to face multinational companies working on indigenous lands and with the task of defending traditionally excluded subjects in the indigenous world such as women and religious minorities. 
The inclusion of rights in the constitutions provided indigenous peoples with a language that allowed them to fight their struggles with the legitimacy of fighting for their constitutional and international rights. Their mobilization started as a mobilization for rights and ended in the 1990 s as a mobilization for a Court's decision, falling into the traps of legal liberalism, that is, confusing a constitutional decision with changes in reality (MayburyLewis, 2002; Kalman, 1996; Scheingold, 1974). In the last 10 years their mobilization has gone back to struggles for new and old rights, as the right to the territory understood as habitat; the right to biodiversity; and the right to rural development. Local and global networks have been important in their relations with the state, but they alone do not explain the emergence of indigenous peoples's struggles in Latin America (Ullóa, 2004).

Unlike other social movements, identified in terms of social class, like the worker's movement; or in terms of identity, like women's movement; in the case of the indigenous movement it is very difficult to make the separation between class and identity, given that such an analysis would be incomplete. These movements represent a challenge to mainstream models of development, but also to liberal democracy. Indigenous peoples understand that the recognition of equality is not enough; they also demand their right to difference, that is, access to special rights as indigenous peoples. In terms of political participation, in Colombia and Venezuela they claim exclusive rights as indigenous peoples; whereas in Bolivia and Ecuador the recognition of indigenous people's rights is seen as part of a more radical transformation of the state that is translated into the idea of a communitarian plurinational state.

The emergence of indigenous mobilization in Colombia is explained as the result of a crisis at three levels: a crisis of representation, brought about by the lack of political parties with enough representation to convey all collectives' interests; a crisis of participation, that is the result of the lack of citizens' participation in state's business; and a legitimation crisis, due to the fact of discrimination against some social groups (Van Cott, 2000: 1). According to Dugas and Van Cott, Colombian elites responded to this crisis by opening the political system to new subjects like indigenous peoples and 
Afro-Colombians. The emergence of indigenous mobilization is the result of elites' rational choice and the institutional transformation occurred after the 1991 Constitution (Dugas, 1993).

In my opinion, indigenous mobilization in Latin America is the result of transformations occurred within social movements, where class-based claims lose their centrality and new claims emerged in public discussions as a consequence of the emergence of new social groups. The links between Colombian indigenous organizations and organizations from other countries allowed the creation of national and international networks that gave indigenous peoples the power to exercise pressure at the local, the national, and the international level (Alvarez \& Escobar, 1992; Alvarez, Escobar \& Dagnino, 2001). Traditional social movements failed in achieving their agendas. Indigenous peoples' mobilization shifted from class-based claims to identity-based claims and new forms of mobilization. In sum, indigenous mobilization is the result of a complex combination of local mobilization, transnational networks and new ways of understanding constitutional and legal rights. Indigenous peoples have broadened the boarders of institutional politics, but also have given new meaning to old notions of citizenship, representation and political participation and, as a result, of democracy (Alvarez, Escobar \& Dagnino, 2001: 18).

In their struggle for their rights, indigenous peoples abandoned the 1980 s armed struggle and the new strategy includes forms of legal liberalism, a politics of identity and the use of transnational networks to pressure the Colombian state to recognize and respect indigenous rights. They have not always been successful and in many cases they fell victims of the cultural project of neoliberalism. Besides the cultural achievements there was an increase in the acts of persecution and in the number of crimes committed against them. This can be termed and the paradox of the permitted Indian, which I will revisit at the end of this paper. 


\section{THE EMERGENCE OF INDIGENOUS MOBILIZATION IN LATIN AMERICA}

The construction of Latin American nations is the result of a process that began with the wars of independence in 19th century. Latin American countries wanted to achieve the levels of progress that Europe had, and local elites found that the only way to do it was by having the same demographics of these countries. That meant the increase of "white" populations and the reduction/elimination of indigenous peoples and people of African descent. As a result, Colombian elites developed policies of whitening of indigenous and black populations; privatization of lands; and transformation of indigenous identities in order to make them peasants, that is to change their indigenous identity for a class-based identity. Independence brought about exclusive citizenship regimes, setting the bases for the struggles of inclusion that characterized the 19th and 20th century (Anderson, 2001; Munera, 2005; Yashar, 204; Rojas, 2002).

The process of constitution of Colombian nation was similar and was not done without resistance and negotiations between elites and indigenous peoples. However, elites imagined their nation as white, male and middle class and an indigenous presence was an obstacle in their attempts to build it. In 1940, Latin American governments met to create the Instituto Indigenista Interamericano and celebrated the I Congreso Indigenista Interamericano, which tried to shape national policies with regard to indigenous peoples. Despite the indigenous agenda in these meetings, that included the state's recognition of their cultural difference, the policies of indigenismo seek the inclusions of indigenous peoples via their assimilation to an already constituted nation, that is, if they wanted to be part of the nation and enjoy the rights of citizenship they had to renounce their indigenous identity: to become Colombians they had to stop being Indigenous (Barona, 1993; Campos, 2003; Coronado, 2009; Bernal, 2009).

The indigenismo movement was a failure at two levels: at the level of inclusion and assimilation, because it did not achieve neither; and at the level of 
protection of the rights of indigenous peoples, creating in its stead divisions amongst the indigenous communities. However, it had the paradoxical effect of creating an international platform for the emergence of new social actors and for the articulation at the local and Latin American level of their networks. This paradox saw its effects in the 1970s when a wave of mobilization suddenly emerged throughout the region. In Ecuador indigenous peoples organized to fight transnational oil companies that exploited indigenous territories; in Colombia, the Nasa people of Cauca recovered old forms of organization and created the Consejo Regional Indígena del Cauca CRIC. From the 1970 indigenous peoples' mobilization became more visible. They were closer to leftist social movements and organizations, but again there were tensions between class-based claims and identity-based claims. At the end, indigenous peoples found in leftist organizations the same racism and exclusion that was common in local elites.

Given this exclusion, and the pressures exercised by the state and the education policies promoted by national governments, indigenous peoples moved to identity claims. They defended their ethnic difference and demanded the protection of their rights as indigenous peoples (Ulloa, 2004:19).

The commemoration of the 500 years of the discovery of the Americas brought a new space wherein they could denounce the oppression that affected them and also they could show the racist constitution of Latin American nations. These events were seen as opportunities to show the oppressive character of the discovery and to make visible their demands at a broader level and celebrate 500 years of indigenous resistance. It is no coincidence that all around the region indigenous peoples organized and marched against the celebration of the "Discovery". In Ecuador the protest took the form of the Levantamiento Indígena in 1990 and centered around the respect to difference; in Mexico, once the North American Free Trade Agreement NASA entered into force, the Ejercito Zapatista de Liberación Nacional EZLN emerged as an organization that fought not only the Mexican government but also the modern capitalist world system. Indigenous resistance became stronger in Ecuador, Colombia, Mexico and Bolivia, and it gave symbolic power to those indigenous groups in countries like Peru and Venezuela. 
Even though each movement has its own agenda, it is safe to say that there is a core of indigenous demands. They can be presented in the following way:

- Recognition of their difference as indigenous peoples.

- Display of an ethnic identity centered around the ancestral and traditional but in continuous dialogue with the modern.

- Construction of new models of discourses of identity with some aspects that are related to environmental claims.

- Establishment of pan-indigenous relations at the local, national, and transnational levels.

- Demands for more autonomy in their territories and in the management of their resources (Assies, 2002; Ulloa, 2004).

One of the most important and cited documents in indigenous mobilization is the 1971 Barbados Declaration. This declaration is the result of a meeting in Barbados in 1971 where 15 anthropologists met to discuss the situation of indigenous peoples in the Americas. Despite not being an original indigenous document, indigenous peoples have adopted as its own because of the importance and commitment of those who signed it. The final report of the event stressed the fact that indigenous peoples have to live between assimilationist policies and policies that seek their extermination. Given that states are responsible for the rights of its citizens, the declaration included demands to the state to guarantee the following indigenous peoples' rights:

- The right to identity.

- The right to the land and territory.

- The right to have their own legal system and jurisdiction.

- The right to be protected from attacks both from the state and from private corporations.

- The right, in the case of non-contacted peoples, to avoid all contacts with the western world, because of the dangers that can bring to their health.

Taking into account that the state is responsible for the actions of its populations, the declaration also demanded the creation of a sort of central authority that deals with the designing and implementation of policies related to indigenous peoples (1971 Barbados Declaration). The group met twice in 1977 and 1993, and in both cases made a call for autonomy and protection of indigenous cultures. 
As it was mentioned earlier, indigenous mobilization brought about a shift in the elites response towards their claims. Several Latin American countries passed new constitutions including the recognition of some rights for the indigenous peoples; this was the case of Colombia, Ecuador and Bolivia. However, in other countries the process of constitutionalization has not been as successful. In Guatemala, in spite of the fact of the inclusion of indigenous rights in the 1996 Peace Accords and the recognition of the importance of addressing the Indigenous question to achieve a sustainable peace, indigenous rights have not been included in the constitution and the fact is that many of the regimes of exclusion that were common coin during the war still remain. It is safe to say that Latin American constitutions have recognized a kind of multicultural liberalism that allows for the inclusion of indigenous right to quiet protests, but that tries not to go too far, either by not including many rights, or by impeding their implementation with the use of violence. The multicultural model has the following features:

- Rhetorical recognition of the existence of indigenous peoples as collective subjects that precede the emergence of the Nation-State.

- Recognition of indigenous laws as binding for the state, but limited by international human rights law and some other constitutional rights.

- Protection of the collective right to the territory.

- Recognition of indigenous languages as the official language in the territory they are spoken.

- Access to bilingual and intercultural education (Van Cott, 2008: 132).

Despite this recognition, we see in the region a continuous negotiation of citizenship regimes in neoliberal and multicultural states. States have tried to solve these tensions in their constitutions, but very often they have been unable to do it, and for that reason social movements and indigenous movements have appealed to strategic litigation in order to obtain a response to their claims from the Courts. But in terms of development and protection of rights the results of these struggles are meager. Indigenous mobilization has been responded with violence and in other cases with forms of neoliberal governmentality that have shown an extraordinary ability to disperse and weaken indigenous struggles and mobilization (Benavides, 2009). 
The struggles for inclusion and changes in citizenship regimes have been important in Latin America, but the cases of Bolivia and Ecuador are perhaps the most important in the region, not only for their impressive results, but mainly because of their organization and the ability to articulate their demands with the demands of other social movements, increasing in that way the strength of their mobilization.

The Ecuadoran indigenous movement emerged in the 1970s, associated to class-based claims, as did other groups in Latin America. In the 1990 s they became stronger and managed to advance proposals that included other social groups, which brought them more support and gave them more legitimacy. However their participation in Lucio Gutierrez' administration weakened their position both with regard to the state and to their own constituency. According to Zamosc, the Ecuadoran indigenous movement is currently suffering and ideological crisis that has to be overcome in order to be able to build the communitarian plurinational state (Zamosc, 2007). At the same time, there is a division within the indigenous movement between the Amazonian organizations and the Andean organizations. In order to achieve the unity of the movement, both organizations have to negotiate their claims, but this is very difficult, given the radical differences between the two of them. In terms of political partisan participation, the challenges are the following:

- The movement needs to define their political project. Given that the movement lost its non-indigenous members it is necessary to determine whether they will have an ethnic party or a more general one.

- The redefinition of the political agenda will determine their opposition with regard to the creation of a plurinational state.

- Given the problems that they had as members of the government, it is necessary to design an agenda to rule the country in order to be ready when they come back to be government.

- In terms of representatives it is necessary to control the process of selection of candidates, given the scandals of corruption that affected some indigenous representatives (Sánchez, 2007: 385).

In Bolivia the challenges are different, mainly because of the fact that they won the elections and that Evo Morales became the first indigenous person to 
be elected president in Latin America. With Morales' election a long process of mobilization was consolidated. After the election, the challenge has been the re-imagination of the state and the construction of a communitarian plurinational state, with the goal of having a more participatory democracy, a more social role for the state and more presence and visibility of indigenous peoples within the state's structure.

Peru has remained as the exception in indigenous mobilization in Latin America. This was due to the agrarian reform set up by the military government of Juan Velasco Alvarado that imposed peasant identities instead of indigenous ones; the bloody persecution they suffer from Shining Path and the fact that this guerrilla claimed to be acting on behalf of indigenous peoples; and the migration to the cities as a consequence of the war and poverty and the resulting loss of indigenous identity. Under Fujimori's and Toledo's administrations there were some attempts of improvement but in the end the situation remain unchanged. Things did not get better under Alan Garcia's second term, because it is a known fact his opposition to indigenous rights because he considers them an obstacle to the country's development (Gorriti, 1990; de la Cadena, 2006). The recent events in Bagua are the result of both the emergence of indigenous mobilization and the stubborn resistance of Garcia's administration to recognize indigenous peoples' rights.

\section{THE EMERGENCE OF INDIGENOUS MOBILIZATION IN COLOMBIA}

Indigenous peoples have combined different strategies in their mobilization in Colombia. Throughout the colony and the Republic they got some good results, like law 89/1890. A combination of armed struggle and legal fights led to the process of incorporation of indigenous rights in the 1991 Constitution. But the way the Constitutional Court decided those cases that involved indigenous rights led to the demobilization of the movement, because this kind of legal liberalism made them consider legal strategies as 
the only indigenous strategy, leaving in the power of lawyers and Courts the movement's fate.

Since 1832 the Republic promoted the division of resguardos as part of a process of privatization of all lands and as part of a process of liberalization of indigenous peoples. Despite Law 89/1890, that was thought to be temporary, resguardos were divided and an unjust system of exploitation of indigenous peoples was established (Espinosa, 2007: 406). As a response to the attacks from the white colonizers in the region of Cauca, the Nasa people organized and fought the attempts of these elites. The regime that the Republic left to indigenous peoples was one wherein they did not have the right to vote, they did not have political representation, and the political system was open only to white settlers as long as they were male, literate, and propertied. Political division in the country, which ended up in the "War of the One Thousand Days", reached indigenous peoples, and they took part in these disputes defending their interests but on the side of one of the contenders in the battle (Campos, 2003).

Due to the liberalization of the lands occurred in the 19th century, indigenous peoples were deprived of their own lands, which were given to white landowners. When the Department of the Great Cauca was dissolved and the Department of Valle del Cauca was created, the elites in Cauca had to look for new ways to promote commerce and capitalism in the region. Caucan elites faced economic expansion in the sugar cane haciendas in Valle del Cauca, coffee activities in Antioquia, and mining in Chocó, with the resulting reduction of their economic activities and income. Since 1904, after the end of the war, Caucan elites imposed some restrictive measures upon the indigenous peoples inhabiting this area: they imposed fences on the territories, they prohibited them to grow plants in the mountains, and they started a policy of modernization of the haciendas with the resulting effects on the labor force.

Indigenous peoples organized and chose Quintin Lame as their representative and defender. The movement, known as La Quintinada, resisted the system of terrajeria and defended the resguardo and the Cabildos that were under attack by the white elites of Cauca. In his speeches, Quintin Lame asked 
why the white owners based all his arbitrary measures on a piece of paper (the law). Given that the injustices committed against the Indians were based on Colombian laws, Lame started to learn them and used them in his communications with local authorities. As a result people, mocking him, started calling him Doctor Quintinito (Castrillón, 1973: 73).

Rappaport presents La Quintinada's demands in the following way:

1. Defense of the resguardo against attempts to divide it;

2. Consolidation of the cabildo as a center of political authority and organizing;

3. The reclaiming of lands usurped by landlords and the rejection of titles not based on royal decrees;

4. Refusal by sharecroppers to pay rent;

5. A reaffirmation of indigenous cultural values and a rejection of racial and cultural discrimination (Rappaport, 2005: 114).

An important part of Lame's organizing process was the use of law. In 1914 he moved to Bogotá and sent letters to the Minister of Internal Affairs, to the Supreme Court, and had interviews with the President of the Republic, in order to get recognition as defender and representative of the indigenous communities. The movement brought about alarm in Bogota's elites, who saw with concern the resistance to the exploitation in Cauca, but also Lame's intention to recover the colonial titles of the Resguardos and to create a small republic of Indians (una República Chiquita de Indios). Lame said in his meetings that they had to keep the struggle until the government recognized and respected the titles indigenous peoples had. The government responded arresting Lame for the crime of rebellion, robbery, and even libel, because of the accusation he was doing against the white elites (Castrillón, 1973).

Lame's use of law was criticized by most of his followers at the time. They thought that this alternative was going to demobilize their movement and in any case that it was going to legitimize republican law. Lame and indigenous peoples used law $89 / 1890$ as a mechanism in their struggles, as it was the case of indigenous representatives in the National Constituent Assembly in 1991. In the case of Nasa people, they use and defend colonial titles as part of a tradition of resistance and historical interpretation that is also part of 
a consciousness of political struggle wherein they militate against both the colonial state and the republican state (Espinosa, 2007: 418).

But Lame's legal strategy was most of the times unsuccessful and this brought criticism because he was seen as someone who believed too much in white institutions. Given the failure of the legal strategy, Lame decided to pursue another path. By the end of 1914 he and his followers decided to take their lands back in order to distribute them equally and in that way recovering the rights that were taken by the Caucan elites. Lame gathered 80 indigenous persons ready to fight against the white landowners constituting in that way the first known indigenous guerrilla in Colombia. ${ }^{1}$ The rebellion got deeper into the indigenous conscience and they decided to keep the fight. Landowners realized that indigenous peoples were organized and that what was used to control them, law 89/1890, was responsible for their organization. They suggested a reform to the law, in order to control the appointment of Caciques. According to the Minister of Government, indigenous peoples lacked the skill to rule themselves, they lacked initiative, had no capital and had not goals for their lands, and therefore they needed white control and government.

Regarding their right to the lands, Quintin Lame wrote about ancestral rights that are above the laws of the republic. Against law 57/1887, that abolished all colonial laws in the territory of the Republic, and in that sense it did not recognize indigenous peoples' rights, Quintin Lame wrote in 1916 that their right to the land did not finish with the passing of time, because their rights do not end thanks to the power of the higher force (Restrepo, 2009: 102). He rejected legal treatment of Indians as children and, showing his socialist influence, he saw law as a bourgeois instrument used by the white landowners to deprive indigenous peoples of their lands. In the text El Derecho de la Raza indígena en Colombia ante todo. El misterio de la naturaleza educa al salvaje indígena en el desierto (Romero, 2005), Lame criticized national laws that commanded indigenous peoples to divide their common lands, as part of the process of liberalization of lands and individuals. In this text, Lame

1. Las Montoneras were made up with indigenous soldiers but they did not fight just for indigenous rights. 
appeals to the idea of real equality and asks why the law does not command white people to divide their own land, and it orders only indigenous peoples to do it (Lame in Romero, 2005: 471).

In 1939 Lame finished Pensamientos del Indio que se educó dentro de las selvas colombianas, his most known treatise. This text became a sort of manifesto for the indigenous movement after Lame's death. The book, published in 1971, became a powerful testimony and a symbol of ethnic resistance for the young indigenous intellectuals who created the Consejo Regional Indígena del Cauca CRIC and the Consejo Regional Indígena del Tolima CRIT (Espinosa, 2007: 421). Lame's use of law was part of his interpellation to western civilization. He asked about the right of conquest of the white elites and the right indigenous peoples have to their own culture and their lands. Lame played in a space of in-between, that is, a space that recognized the power of law, which used it as part of the strategies in the indigenous struggles, but that it also recognized the possibility of armed struggle. But Lame's obsession with law led to his silencing and the demobilization of his movement and the final victory of the white elites in Cauca and Tolima (Espinosa, 2004; Espinosa, 2007: 424).

The history of the indigenous movement cannot be understood without the history of popular mobilization in the 2oth century and the attempts of the government to control social movements by creating governmental unions and social organizations that were supposed to be at the service of the state (Uribe, 2007). This form of corporatism, taken from the Mexican experience, proved to be unsuccessful and, on the contrary, it put together various intellectuals that later on would take part in movements like the indigenous movement in Cauca and Tolima.

The 1960 s was a time of social unrest in Colombia. After the end of Gustavo Rojas Pinilla's dictatorship (1953-1958), Colombia entered a period of pacted democracy, that is, a period in which the two political parties involved in the struggles known as La Violencia decided to share power and therefore to established a system of alternation in the presidency. This kind of democracy did eliminate violence between the conservative and the liberal parties, but the closing of the political system and the lack of solution to social conflicts 
yielded to a new kind of conflicts and actors (Sánchez, 2007; Sánchez, 1991). The left became more important in the popular sector, there were more processes of organization of the movements and the example of the Cuban Revolution opened the path to new guerrilla movements like the Ejército de Liberaciòn Nacional ELN and the Fuerzas Armadas Revolucionarias de Colombia FARC.

Agrarian conflicts existed in Colombia at least since the beginning of the 2oth century and they led to the mobilization of peasants and indigenous peoples, like the Quintinada in the region of Cauca and the lamismo in Tolima. But the government tried to solve the problem without actually depriving landowners of their lands by promoting a limited agrarian reform and by establishing a sort of capitalism that continued the exploitation of peasants in the countryside (Múnera, 1998). ANUC was created to organize peasants and just some years after its creation it had more than two million members. This number is impressive taking into account that in Colombia there were at the time some nine million peasants.

Despite the fact that ANUC did not achieve important results, it did represent an important organization of the peasant movement. But perhaps its most important result was the organization of indigenous intellectuals who found a space of political education (Bonilla, 1977). After the Quintinada's failure, and the failure of the unions to organize indigenous peoples, mainly because it did not recognize the specificity of indigenous worldview, Nasa people started a new process of organization that coincided with the guerrilla struggles and the creation of ANUC.

In 1963 some Guambiano and Nasa leaders created what they called the Sindicato del Oriente Caucano, which properly speaking was not a union, but an organization that vindicated their right to the land and to have an autonomous government. In their process of organization they joined forces, which eliminated the old disputes between Guambianos and Nasa people; they found that the Cabildo as a form of political government was important in the political organization of the indigenous peoples; and they also found that the struggles to recover their lands were important in the indigenous movement and the indigenous identity. 
Both the Sindicato and the ANUC did not represent the interests of indigenous peoples. The failure of these two organizations showed indigenous peoples the need to have their own organization. With that purpose in 1971 it was created the Consejo Regional Indígena del Cauca CRIC. As the leaders of the indigenous movement stressed it, indigenous struggles are part of peasant struggles, because of the similarities in terms of agrarian reform and dispossessing of the land, but this does not mean that indigenous struggles do not have their own specificity (CRIC, 1981). The CRIC was born as a result of the organization of indigenous peoples in two assemblies that discussed their rights. In 1971 more than 2000 indigenous persons gathered in Toribío (Cauca) to publicly discuss their rights. White landowners got scared because of this organization and ordered the police to illegally arrest Gustavo Mejia, president of the Federación Social Agraria, who helped to organize the Assembly. The Assembly discussed the following points:

1. Demands to the government to give back the lands that were part of the resguardos.

2. Demands to the government to extend the agrarian reform to give more land for the resguardos.

3. The modification of Law $89 / 1890$ in order to recognize indigenous peoples as citizens.

4. Participation of the indigenous leaders in the reform of this law because they are the ones who know better about their situation.

5. Elimination of the División de Asuntos Indígenas of the Minister of Internal Affairs, because of its lack of efficiency in dealing with indigenous matters (CRIC, 1971: 11).

Indigenous intellectuals felt that the existing social organizations did not take into account their rights and their worldview. Regarding ANUC, they saw that the government influenced and controlled this organization. As a result, indigenous leaders that were part of ANUC and advised by the Movement of Popular Unity, decided to have an assembly where the indigenous worldview and the struggle for the right to the land and to their own government were the central issues for the discussion and the struggle. On September 6th 1971, indigenous peoples of Cauca organized a second 
conference, this time in La Susana, near the town of Tacueyó, Department of Cauca. The program that was approved is the following:

1. Recovering the lands of the resguardos.

2. To have more lands for the resguardos.

3. To strengthen the political power of the Cabildos, as the main indigenous authority.

4. To stop paying the terraje.

5. To have the government know the indigenous laws and strictly enforce them.

6. To defend indigenous history, language, and customs.

7. To educate indigenous professors in order to have education in that language and with a proper knowledge of the indigenous situation. The main tool of the CRIC in its struggle to recover the land was precisely the takings of lands. CRIC's struggle was justified because of the struggle to recover the land and to reestablish resguardos and cabildos in Cauca (CRIC, 1971: 14). In the first three years of the movement, they recovered more than 5000 ht of land in contrast with the 8000 ht negotiated by the government in ten years of work (CRIC, 1971: 14). During the first years of struggle of the movement they presented two trends: one, that saw the movement as one that recognized only the ethnic part of the claims and that was labeled as an indigenist position; another, that is present in other social organizations that take into account only the idea of class exploitation, and putting aside or postponing the indigenous claims as less important.

CRIC is one organization that tried to combine class and race claims, since indigenous peoples are exploited as both indigenous and peasants. CRIC wanted to combine class struggles with indigenous ones, given their condition as indigenous peasants (CRIC, 1971: 69). In the document presented in III Peasant National Congress, the indigenous secretariat of ANUC and CRIC held a position that set the limits of the class struggle regarding indigenous rights. In this document, they showed that indigenous peoples are peasants, but that they have a worldview that makes them different from everybody else, for instance their view of the land as something more than just an economic good and the importance of culture in their everyday life. In 
the conclusion of this document, written on August 31st 1974, indigenous leaders held:

"Indigenous peoples know that we constitute a small minority within the exploited masses and that we by ourselves will not be able to achieve the smallest conquest in our claims.

Our hope is to contribute to the process of liberation of Colombia, fighting shoulder by shoulder with peasants, workers, and all the exploited, in coordination with their class organizations.

In the construction of a new society we could give our own contribution, like other national minorities that are fully contributing to the advancement of peoples that have already began the path of their emancipation.

When Colombians are consolidating our personality as a nation, indigenous peoples will not be able to be absent, because based on persecution and sufferings we have kept the roots of an authentic and millenary culture (CRIC, 1981: 170)."

From the very beginning of indigenous mobilization and due to the challenge that their protest meant for the privileges of white elites in Cauca they were object of constant attacks by the police and paramilitary groups serving the interest of the Caucan white elites (Toro, 1994: 39). Indigenous organizations asked guerrilla movements for help but the latter promised to help in exchange of control over the activities and ideology of the indigenous organizations. This provoked a break up between indigenous organizations like CRIC and guerrilla groups like FARC, ELN and M-19. As one woman part of the Quintin Lame stated: “The Quintin Lame was born out of necessity, and it became clandestine. At the beginning they had contacts with M-19 for the military training. But after the takings of land in Tierradentro and the death of Padre Alvaro Ulcue the movement grew stronger" (In Toro, 1994: 40).

The Quintin Lame recruited its members from their own communities but they were not supposed to spend more than 8 months in the group, it was a sort of minga to protect the community from the attacks of FARC and the landowners. The organization had limited action not only due to its lack of resources but mainly because of the goals of the organization: not to take 
power but to fight an indigenous struggle that involved the recovery of the lands for the resguardos (Toro, 1994: 51). But as former M-19 commander Otty Patiño said, the armed arm did not think and tried to act on its own generating fights between the leadership of the CRIC and the Quintin Lame (Interview with Otty Patiño, Medellín September 11th 2005).

Ricardo Peñaranda holds that the Movement Quintin Lame has the following features: first, it was created from within the indigenous movement, especially CRIC, in order to defend it from the attacks of the landowners and their paramilitaries also known as pájaros (Birds); second, there was a close connection between the group and the local population; third, the struggle for the land and the community mechanisms of social control led to a process that brought about a sort of local revolution; fourth, the initial success of the guerrilla group created an unbalance with the indigenous movement and created the need to dismantle the group to prevent the dismantling of the social movement; and, fifth, the successful demobilization and the rights guaranteed were the result of the fact that indigenous peoples comprised a mere $2 \%$ of Colombian population (Peñaranda, 1998).

Given the attacks from the government and their success in decimating the Quintin Lame, some of its members suggested completely dismantling the movement in silence. As a matter of fact, once the government recognized their importance for the peace talks, they went back to the movement just for the ritual of demobilization. The armed struggle of the Quintin Lame had the rejection of indigenous organizations, not because of the armed struggle in itself, but because of the orientation given to the armed struggle. A communique of the indigenous authorities said that what makes and indigenous armed struggle is not the fact that indigenous persons hold arms, but the thought that leads them, and in the case of the Quintin Lame that thought got lost in the struggle (In Peñaranda, 1998: 162).

After the attacks to the Palace of Justice, there seemed to be an end to all the peace processes existing in Colombia. In the late 1980 s there was a new peace process brought about by some of the actions of M-19. Given the progressive lost of prestige that the Quintin Lame was having, and the problems it was causing in the indigenous communities and the indigenous organizations, it 
was imperative to demobilize the movement. Oty Patiño, former commander of M-19, said that the moment was the best for Quintin Lame because it gave them the opportunity to do something they nevertheless had to do, and in the process they got something in exchange for their demobilization (Interview with Oty Patiño, 9/11/2005). The reasons that led to the Quintin Lame's demobilization were the following: first, the lack of military strength, that made them vulnerable to the paramilitary groups organized and supported by the Army and by drug lords; the lack of control to common delinquency and the participation of some of its members in those acts; the loss of support from social organizations, because the movement became an obstacle to the social work being done by indigenous organizations like CRIC; the possibility that if they did not participate in the peace process they were going to be absorbed by groups like FARC or ELN, with the negative consequences for the social organizations and the indigenous communities (Peñaranda, 1998: 174).

It is important to take into account that at the time of the demobilization the indigenous communities in Cauca had recovered about $75 \%$ of the lands that historically had belonged to the Resguardo, that is, the reasons for the existence of the movement were exhausting and what was left was the war without any indigenous goal. However, despite the fact that the period of military expansion of the movement coincides with the period with most recuperation of lands, it is important to notice that indigenous communities and CRIC were the ones who fought hard and recovered their lands. The armed movement served as a sort of protection for the communities, but once the white elites resorted to the army and to paramilitaries, the protection the Quintin Lame could give was minimal.

The leadership of the Quintin Lame could not replace the actions of the communities, and for that reason they did not participate directly in the recovery of lands. After the peace process, guerrilla warfare became an obstacle in the relations between the state and the indigenous communities, and therefore the demobilization of the movement was an important step in the legalization of the Resguardos and the expansion of the social movement (Medina, 2003). As a result of all these arguments, the Quintin Lame 
participated in the peace process with the Barco administration (1986-1990) and finally signed the peace agreement on may 31st 1991 after almost three years of negotiation, simply because the government did not pay attention to the movement, and thought that it was unnecessary to participate in a peace process with a group that the government thought to be weak or to not represent the interests of the indigenous organizations.

In a letter written on August 9th/1990, Jesus Peña Chepe complained for the non inclusion of indigenous rights in the discussions about the creation of a National Assembly, he held that the assembly was not taking into account an important group in Colombia that could not be reduced to the mere role of witnesses and victims of political events in the country (In Peñaranda, 1998: 204). On December 6th/1990 there were elections for delegates to the National Constituent Assembly, but it was only until may 27th/1991 that the Quintin Lame decommissioned all their arms and it finally had representation, without the right to vote, in the drafting of the 1991 Constitution.

Once in the Constituent Assembly, the three indigenous delegates proposed the inclusion of indigenous rights and the recognition of the right to have an autonomous government. The 1991 Constitution included several rights for indigenous peoples but it did it within a framework that brought about a tension between universal rights and indigenous rights. This tension did not have a solution in the text of the constitution but it was "solved" in a universalist way by the Constitutional Court (Bonilla, 2006).

One of the provisions of the 1991 Colombian Constitution is the creation of a special circumscription for indigenous candidates. In the 1990 s and with clear electoral purposes three political organizations were created: the Alianza Social Indígena in 1991; the Movimiento Indígena Colombiano in 1993; and the movement Autoridades Indígenas de Colombia AICO in 1994. The new political parties allowed for more indigenous participation at the local level, but at the same time they created divisions amongst the indigenous movement. During the period 1991-1994, indigenous political participation was low, and paradoxically they got more support in urban areas that in rural and indigenous areas. Their fragmentation led to a defeat in local elections but with some hope at the national level. In the local elections in 1997 and in 
the elections for Congress in 1998 there was a slight increase in votes. But it is during the period 2001-2002 that indigenous representation increased up to a point of electing an indigenous governor in the region of Cauca (Laurent, 1997; Laurent, 2005).

Currently indigenous participation in Congress and in local elections remains low, and this is due to several reasons: the fragmentation of the movement; the loss of the vote from non indigenous leaders, mainly because of the loss of the novelty of indigenous political participation; low number of voters -we have to remember that they comprise 2 to $3 \%$ of Colombian population, mainly people living in the countryside without access to the places where ballots are casted; and in the last two elections because of a phenomenon that completely changed the panorama of Colombian political system: paramilitary involvement in political elections (Valencia et al, 2007).

The transit from movement to political parties has been difficult, because they have different logics. While social movements are ruled base on leadership and discipline; political parties are ruled by individualism and competition. If ethnic parties want to succeed in Latin American political systems, they have to be able to respond to these challenges:

- The selection of candidates has to be the result of clear rules in order to avoid divisions within the movement.

- Resources are scarce, and participation in political parties can lead indigenous leaders out of their communities and make them focus more on national politics, with detriment to the indigenous representation.

- The coexistence between the movement and the party can lead to confusion, because of the different hierarchies and agendas. However indigenous peoples have developed democratic practices in order to overcome this obstacle.

- Women's participation is one task that needs to be fulfilled, because so far indigenous women remain marginalized in these already marginal political subjects. 


\section{INDIGENOUS RESISTANCE}

According to ONIC there are 102 indigenous peoples in Colombia, but only 82 recognized by the Colombian government. One of the main problems indigenous peoples are currently facing in Colombia is the lack of recognition of their right to be consulted. Not only armed actors are attacking indigenous peoples, but they are also attacked by the government with legal strategies that seek to impose government's projects on indigenous lands without consulting them. Colombian government understands the right to be consulted as simply informing indigenous organizations of the projects they try to develop in workshops where this information is given to a few. The government does not respect the process by which indigenous peoples make their decisions and the importance that for indigenous organizations have the voice of all indigenous peoples. In Colombia there are several organizations that defend their rights at the local level, like the Organización Indígena de Antioquia OIA; the Consejo Regional Indígena del Cauca CRIC; the Organización Regional del Valle del Cauca OREWA, amongst others. But it is in 1982 that indigenous organizations created the National Organization of Indigenous Peoples ONIC, which is the most important national indigenous organization in Colombia. The demands and what they call the platform for the struggle are comprised of the following points:

- Defense of indigenous autonomy

- Defense of indigenous territory, recovery of lands, and protection of resguardos.

- Control of natural resources on indigenous territories.

- Support to indigenous organizations in the development of economic communitarian projects.

- Defense of indigenous history, traditions, and culture.

- Bilingual and bicultural education under indigenous control.

- Recovery of traditional medicine and claims to have health programs with the communities social and cultural features.

- Demands for the respect of law 89/1890 and all laws that protect indigenous rights. 
- Solidarity with other sector's struggles (www.onic.org last visit September 28th 2009)

ONIC works for the protection of indigenous rights, especially for more autonomy and more self-determination. To ONIC there is a need of a new conception of the state wherein there is a multicultural nation that integrates all subaltern groups with equal rights. The right to autonomy means in that way political, social, cultural, and economic autonomy. Indigenous organizations claim their right to control cultural change within their territories, that is to say, they claim an intercultural exchange between peoples based on the respect of indigenous peoples' rights. The imposition of other cultural models lead to the abandonment of indigenous cultural models and to displacement and the extinction of the community. Extractive economies bring about this effect, because they separate culture from territory; the government and state institutions do not respect and recognize indigenous rights; and guerrillas try to recruit members of indigenous peoples affecting their indigenous identity and their commitment to peace (Houghton \& Villa, 2005; Houghton, 2007).

One of the most interesting strategies of resistance is the Indigenous Guard. If the 1980 s were marked by a belief in armed actions, the 1990 s and 2000 s are marked by the firm belief that armed resistance can affect the unity of the indigenous movement. Peaceful forms of resistance are more in accord with the indigenous worldview and they can be traced back to the 18th and 19th century. The Indigenous Guard is seen as an indigenous contribution to the construction of a culture of peace, with the purpose of having all combatants in the Colombian armed conflict respect international human rights law and international humanitarian law as part of the bases for a lasting and sustainable peace. The Indigenous guard is a non-armed group that through peaceful means defends indigenous peoples' right to autonomy and life. It is conceived as an instrument of resistance, unity and autonomy to defend indigenous territory and their Plan de Vida. It is a mechanism of humanitarian resistance and civil disobedience. They are under the orders of the Indigenous Assembly and are protected only by their batons that give symbolic power to the guard. 
The tasks the Indigenous Guard has are the following:

- Coordinate actions in order to liberate people kidnapped by armed actors operating in Cauca.

- Make agreements with armed actors in order to exclude indigenous peoples from the conflict.

- Make agreements with local narco-traffickers to have them dismantle the drug labs they have on indigenous territories, as part of their strategy to fight the cocalization of the war on drugs.

- In general avoid the effects of armed conflict on indigenous territories.

Indigenous resistance is then a well-organized movement that is generated from the bases and that seek to defend indigenous planes de vida. Their forms of resistance do no admit the use of violence, but that does not mean that violence is excluded completely, but only under extreme circumstances and as a response to violent attacks against them and their organizations. However they recognize the strength of armed actors and the uselessness of facing them with the same arms. On the contrary, they recognize that dialogue and political resistance are the best instruments to face armed violence in Colombia (Hernandez, 2006; Diaz, 2008).

\section{INDIGENOUS PEOPLES AND STRATEGIC LITIGATION}

There have been important developments in international law regarding the rights of indigenous peoples. From being considered an ethnic minority, under ILO Covenant 107/1957 to being treated as a people under ILO Covenant 169/1989 and the 2007 Universal Declaration, indigenous peoples have achieved a broader framework for the protection of their rights. This is a recent development and it is the result of indigenous peoples' mobilization, giving their struggles a legal framework and international legitimacy. Without ILO Covenant 169, for instance, and the right to be consulted recognized in this international instrument, many of the megaprojects that 
transnational companies and the Colombian government try to develop on indigenous lands would have been done, affecting indigenous peoples' lives and existence.

The right to be consulted, the determination of the indigenous identity via self-identification, the right to their territory, to their own systems of justice and health worldviews, have been the most important rights recognized in ILO Covenant 169. Human rights instruments and ILO Covenants are used consistently by the Colombian Constitutional Court in order to protect the rights of indigenous peoples and to solve the cases that are taken to the Courts by indigenous organizations.

In the Inter-American System there have been attempts to pass a declaration on the rights of indigenous peoples, but so far it has found many obstacles, especially from countries like the United States, Canada, Colombia, and Chile, which do not want to recognize indigenous peoples' rights at this level and which see this recognition as an attack on states' sovereignty. Despite this lack of instruments at the Inter-American level, the Inter-American Human Rights Court IHRC has made an interpretation of the American Declaration of Human Rights in a sense that is favorable to indigenous rights (Nash Rojas, 2004). In several cases, the IHRC has recognized the rights of indigenous peoples. The Awas Ringni case (August 31st 2001) is perhaps the most important case at this level. In this case the IHRC found that indigenous peoples' territorial rights come not from the recognition in national laws or from civil law contracts -that are the result of Spanish presence in the Americas and the construction of Latin American republicsbut from the occupation and traditional use of the lands. To the IHRC these are pre-state rights, and for that reason state laws and state sanctioned legal mechanisms cannot affect their existence.

The most relevant transformation in the last years is the Universal Declaration on the rights of Indigenous Peoples, that is the result of more than two decades of negotiations between governments and indigenous organizations. Article 19th of this declaration introduces important changes in the right to be consulted, which is now conceived as having the purpose of achieving free, previous and informed consent. According to the ILO the 
right to be consulted has to follow some steps that at the end shows that the very purpose of this right is precisely achieving free, previous and informed consent from indigenous peoples. However, it is an important change, given the different interpretations governments have been giving to this right. In Colombia, during the discussions in the 1991 Constituent Assembly indigenous rights were incorporated and were part of the discourse of social movements and politicians in order to get the constitutionalization of indigenous rights. However, in the drafts that were presented it was clear that indigenous rights were taken into account and that they were part of the discourse of the government not only during the debates in the Assembly, but also in the project of constitutional reform known as "The Barco Project". In this section I want to focus on the history of the incorporation of indigenous rights in the 1991 Constitution, and then I wish to analyze the constitutional doctrine regarding indigenous rights in order to show that there is a process of nation building that wants to incorporate indigenous peoples from a multicultural perspective. In that sense I agree with Daniel Bonilla, but without the celebratory view, that the 1991 Colombian Constitution is a multicultural constitution (Bonilla, 2006).

Once the Constituent Assembly was created and its members elected, its work focused on four issues: to put an end to violence; strengthen democracy; to broaden the framework of rights and to redefine the basic structure of state institutions (Bonilla, 2006: 121). The Assembly had three representatives for the indigenous peoples and none representing Afro-Colombians. They were: Francisco Rojas Birry, from the Embera Katio people; Lorenzo Muelas, for the Guambiano people; and the Nasa indigenous person Jesus Peña Chepe, who was representing the indigenous guerrilla Movimiento Armado Manuel Quintín Lame MAMQL, and who only had the right to participate in the discussions but no to vote in them. The delegates stressed in the discussion and in their projects the fact that they were taking part in the discussions as a result of 500 years of resistance. They criticized governmental policies that were created to homogenize indigenous peoples because of the government's idea that western values were superior to indigenous peoples' values and cultural traditions. They held that this process had been done 
through the use of law. According to Muelas, "the juridical order that has ruled intercultural relations in Colombia has served to justify for 104 years the assimilationist policies of the Colombian state, based on the belief that western Christian civilization is superior and on the belief of the inevitable disappearance of autoctonous populations" (Gaceta Constitucional No. 40). From a constitutional point of view, delegate Rojas Birry suggested that indigenous rights should be incorporated in the Constitution because in that way Colombians would see that indigenous peoples had special rights because of their special situation (Gaceta Constitucional No. 67).

According to Daniel Bonilla there is a tension between the unity of the nation and the diversity brought by the existence of indigenous rights (Bonilla, 2006). Bonilla considers that the projects that were presented by the indigenous delegates did not solve the tension that exists between the unity of the nation and the recognition of indigenous rights and that it was the job of the Constitutional Court to solve that tension between universalism and cultural rights. However, he does not take into account that this is precisely the claim of indigenous delegates, who stressed a history of 500 years wherein they have been subjects of policies of assimilation and homogenization, a policy that is continued by the Constitutional Court in several of its cases.

\section{THE LIBERALIZATION OF RIGHTS}

The Court had to face the difficult task of implementing the new Constitution and of developing a sort of Constitutional pedagogy. The cases the Court decided were brought by individuals, institutions, and NGOs that wanted to have a clear decision about a topic that was already contained in the Constitution but that it needed a constitutional decision. Before 1991, the role of NGOs was limited to the role of denouncing the Colombian state before international forums and before international courts. After 1991, a new task was set for some NGOs, because they saw their role as one of protecting human rights through the Courts. However they did not realize 
that by appealing to this path, they were accepting the individual character of fundamental rights, mainly because of the doctrine that the Court began to set after 1991.

International law has had several transformations since 1945 and the international law of human rights has become a way to limiting state's sovereignty. Based on this idea, Constitutions have incorporated a sort of "rights in the shadow" clause by which international law can be the law of the nation whenever it is important to limit state sovereignty or whenever it is important to protect individual's rights. One of the roles of the Constitutional Court is the analysis of the treaties celebrated by the executive branch in order to determine if it is possible to incorporate them in the internal order.

Justice Ciro Angarita Barón analyzed the constitutionality of international law regarding Colombian Constitution. In Sentence C574/1992 he analyzed the constitutionality of Protocol I additional to the 1949 Geneva Conventions. According to the Court, the four Geneva Conventions and the Additional Protocols I and II constitute an ethical catalogue that is universal and mandatory for all states. In a very interesting and mistaken interpretation of international law, Justice Angarita holds that international humanitarian law is a jus cogens norm, especially the Geneva Conventions and the Additional Protocols I and II, that is to say, it is customary law that has to be enforced independently from the will of states. That means that Colombian state has to apply these norms, and that they have a status of constitutional law. According to the Court, the principle contained in the Constitution established an axiological system that is international, that is, global, and Colombia cannot escape to that state of affairs.

To the Court, state's sovereignty is limited by these universal principles, and that is the only way to guarantee peace and the protection of an international morality. According to the Court, article 94 of the Colombian Constitution automatically incorporates international law, at least human rights and international humanitarian law, into the Colombian constitutional system, and these norms and principles make up a block with the constitution and because of that these norms are immediately binding. By using the concept of 
block of constitutionality, taken from the French tradition, the Court decided that all international human rights law and international humanitarian law needed not be incorporated into the legal system because they were already part of it, due to the block they formed with the Constitution.

Since human rights and international humanitarian law were considered jus cogens, those rights were binding for the Colombian state even if the Constituent National Assembly did not expressly introduce them. Since they were binding, every individual living under Colombian laws had to be bound by those norms, that is to say, every individual had to respect human rights as defined by the global institutions of governance. In this way, the hegemonic power of universal human rights was imposed through the power of Colombian Constitutional Court, in other words, those rights were redefined in terms of fundamental rights, but taking into account the universal discourse created in the institutions of global governance.

The Court was very shy in the process of implementing fundamental rights. However, in the few initial cases that it decided about indigenous rights, it is very clear that the Court has a very liberal view of rights, that is, a conception that protects the individual and that has a multicultural view of the Colombian state. We find this view in two cases that dealt with indigenous rights and the protection of indigenous communities. In Sentence T428/1992, the Court started to analyze the status of indigenous rights. This is a very interesting case because the Court has been refining its concept of indigenous rights, but in any case it has always sustained the idea that there are universal rights that have to be respected by all Colombians, and cultural rights that belong to particular cultures but that need to be accommodated to the idea of universal rights and universal values. Based on the idea that there are indigenous rights, the Court understood that there is a constitutional obligation to consult all the government's decisions with the indigenous communities. In this case, the government was trying to build a road that was going through indigenous territories, affecting indigenous peoples' right to life.

However, the Court, despite all its multicultural rhetoric, did not deal with the idea of indigenous rights, and in its stead it dealt with the idea of group 
rights, and analyzed how these works affected the possibility of indigenous peoples, or any other group, to live in a place where there is a danger of a natural catastrophe. Given that the government claimed that the road was built in the general benefit, the Court found that in some cases minority rights were prevalent and therefore the idea of general interest did not apply. But what is important about this case is that the Court took for itself the idea of defending and implementing fundamental rights, setting the bases for strategic litigation. Based on the works of Alexander Bickel's, the Court considered that it is the best instrument to guarantee the solution to the tension between security and justice (Bickel, 1962).

At the end, the Court decided in favor of the indigenous community, because in this case the general interest that had to be taken into account was the interest of the community in not having any works in their area without being previously consulted. In Sentence T605/1992, the Court decided a case where fishing rights were under discussion. The Court, following the doctrine previously established, found that indigenous rights are prevalent vis á vis general interest, because there is an obligation of the Colombian state to protect these communities and to guarantee their material equality by protecting them and promoting their welfare.

In 1993 the Court had to decide one of the most important cases of the first period. Colombia had been defined in the 1886 Constitution as a catholic state and therefore the Catholic Church had the right to educate indigenous peoples and to send missions to evangelize indigenous persons who were considered savages. The Covenant between Colombia and the Vatican State, incorporated into the Colombian legal system, was object of a lawsuit before the Constitutional Court because it violated several articles of the 1991 Constitution. The plaintiffs considered that this covenant violated the Constitution because it considered the Church and the Colombian state as equal subjects with the right to educate indigenous peoples. The plaintiffs held that the Church and its missions affect the cultural integrity of indigenous peoples and that they should be protected from this kind of intervention. The Court found several articles of the Covenant to be against the Constitution because it violated the religious autonomy of indigenous 
peoples. However, the Court did not defend an argument based on the idea of indigenous rights, but on the right of individuals to have their own religion and to have a separation between Church and state.

What is interesting about the first cases decided by the Constitutional Court is that they were developing the constitution and indigenous rights from the point of view of minority rights, that is, collective rights of a group of people that where the minority in a certain territory. Social movements had not developed an idea of strategic litigation and therefore they were not using the Court as often as they used it later. The Court defended, in the few cases it had to decide during this period, the idea of collective rights for the indigenous peoples, holding that the territory, for instance, is part of their condition of indigenous peoples' identity and part of their world-view. But despite this assertion, the Court did not develop a doctrine of indigenous rights as indigenous peoples' rights (Decision T188/1993; Decision T257/1993).

But there was a sudden turn in decision T380/1993, where Justice Eduardo Cifuentes, who wrote past decisions dealing with indigenous rights in which the Court considered indigenous rights as collective rights, held that fundamental rights of indigenous peoples could not be confused with the collective rights of other groups. The Court added that an indigenous community is a collective subject and not a simple addition of individuals sharing the same rights or interests. How was it possible for the Court to have a turn in its doctrine? If we see the plaintiffs in the cases the Court decided until this case, we'll see that they did not have any kind of representation for the indigenous peoples, and therefore when there was any kind of defense of indigenous peoples, this was done by lawyers who did not have any link with the indigenous communities and who understood indigenous rights as group rights.

In the case decided with decision $\mathrm{T}_{3} 80 / 1993$, the plaintiff was the indigenous organization of Antioquia, one of the most active social organizations in the country. The case was brought in representation of the Embera people of Chocó, to protect the community from the exploitation of the forest by a private company. The Court held that capitalist exploitation has some limits and that those limits in the case of the territories of the indigenous 
communities are determined by their cultural, social, and economic integrity, such as it is commanded by article 330 of the 1991 Colombian Constitution. In decision T405/1993 the Court considered the Resguardo as a special kind of territory and part of the rights of the indigenous peoples. However, in this decision the Court considered that indigenous rights are fundamental rights that cannot be absolute, that is, they have to respect the clause contained in the constitution that gives indigenous peoples special rights and special jurisdiction as long as they respect universal human rights. It is interesting that this case was about the installation of a DEA's radar. The authorities of the Resguardo sued the government because in the territory of the Resguardo people from the American Army and the American Embassy were installing the radar that was going to be used in the war on drugs. The Court considered that indigenous authorities were right in considering that they had special rights to the territory, but the Court added that these rights were not absolute because the government had the power to celebrate agreements with other governments in these territories, taking into account that it is the Colombian State and not the indigenous peoples the ones with sovereign power in the Colombian territory.

\section{THE CONSOLIDATION OF RIGHTS}

The Constitutional Court started developing a doctrine considering indigenous peoples' rights as collective rights. Then, thanks to the intervention of indigenous advocacy, the Court started talking about indigenous rights as more than collective rights. However, what seemed as a good path the Court was going to follow was immediately changed when the Court had to deal with cases in which the interests of the state were at stake. In these cases the Court considered that the Colombian state was the sovereign power over all the Colombian territory, that is, even in the territory of the indigenous Resguardos, and it considered that it was legal to allow foreign powers, like the United States Army, to set up radars as part of the surveillance that is used in the war on drugs. This doctrine was repeated 
in other cases where the Court defended a restrictive idea of indigenous rights (Decisions To01-1994; T254/1994; T305/1994; T342/1994). When the Court changed six of its members it took a more decisive role, using constitutional cases to definitely determine their understanding of human rights and in doing so the Court constituted indigenous peoples as a global liberal identity.

In 1995, in decision C104-1995, the Colombian Constitutional Court had to decide about the constitutionality of the Covenant for the Development of the Indigenous Peoples. According to this covenant, Indigenous Peoples are those peoples who were living in the country before the Spanish conquest, who kept all their own social, political and cultural institutions or part of them, and who had a conscience of being part of an Indian community. This Covenant had the purpose of incorporating ideas of development in the country and giving indigenous communities funds to support their selfdevelopment. However, the Covenant also substantialized the communities by accepting as indigenous only those members of Indian communities who considered themselves Indians but also who kept traditions unchanged. As we saw earlier, this is the western idea about tradition, that is to say, an idea that conceives tradition as unchanged and modernity as perpetual change. If Indian communities wanted money for development they had to present themselves as traditional in opposition to modern, that is, they had to forget 500 years of historical change and adopt a frozen identity of the past. The Constitutional Court through the use of the acción de tutela has sanctioned this conception. In decision T188/1993 the Court established that the Colombian state was a pluralistic and multiethnic state and that Colombia recognized as Indigenous only those communities that had ties with the original communities of Colombia and kept the original traits of their culture.

The Court considered that to interpret indigenous rights, whenever there are conflicts between occidental values and indigenous values, we have to follow these rules:

1) The more conservation of traditional customs, the more autonomy.

2) Fundamental human rights are the minimum that is mandatory for everyone. 
3) Imperative legal norms are above traditional customs, if they protect some values that are superior to the ethnic and cultural diversity.

4) Traditional customs are above some legal norms, which the Court labels as dispositive.

As a result, the Court considered that there is a tension between universal human rights, but taking into account that international law gives prevalence to human rights above indigenous rights, the Court without further analysis concluded writing that universal human rights are above indigenous rights and that human rights are imperative in the territories of the indigenous communities.

This view is repeated in decision $\mathrm{C} 139 / 1996$ when it decided about the constitutionality of law 189/1890. In this decision the Court found that this law was in accord with the constitution, with the exception of some articles that the Court considered unconstitutional, like the division between civilized, semi-civilized and savages that we find in article 1st of this law. Based on this view of the indigenous person, that was central in the way indigenous peoples were seen during the 19th and 2oth century, the Court considered that indigenous peoples had the right to have jurisdiction on indigenous matters as long as the events happened in the territory of the indigenous peoples and between members of the community, which means that in any other case there is prevalence of the national jurisdiction (Decision 496/1996).

In one of the most famous cases regarding indigenous rights in Colombia, the Court recognized the idea of rights of the indigenous peoples. In this case, Occidental Petroleum Company wanted to exploit some fields that were within the territory of the U'wa People in the eastern part of the Country. The Court considered that the government's decision was made without consultation with the indigenous peoples, and therefore that that action violated the Constitution and Covenant 169/1989 that grants indigenous peoples the right to be consulted whenever there is a governmental decision that affects their interests (Decision SU 039/1997). However, the Court did not recognize the rights of the indigenous peoples as such, because in one decision the same year it decided that they could be compensated for the damages they received when some works were done in their territory 
without previous consultation (Decision T652/1997). That is, to the Courts, indigenous peoples own the land, without taking into account their worldview and the importance of the territory for their identity. For that reason, when the U'wa people claimed that oil is the earth's blood, they claimed that no exploitation could be made in the whole territory, and not just in the surface where they live.

The tension between universal rights and indigenous rights has been object of constant discussion in the Court. In one case the Court had to deal with the freedom of religion of one of the members of the community and the rights of the indigenous people. In this case, one member of the Arwako people professed the protestant religion and in doing so he did not follow the rules of the indigenous authorities. The Court recognized the right of the individual to have his own religion, but at the same time, it decided that the community had the right to punish the individual for not obeying the commands of the community (Decision SU 510/1997). As clear as this case seems, the truth is that the Court did not take into account how the presence of Christian missions is affecting indigenous identity, and how some religions have demobilized indigenous peoples, due to the prohibition to march and mobilize that some Churches impose to the indigenous communities with whom they are working.

In a similar case, the Court decided in favor of the individual because the tradition was against the universal idea of human rights. This case involved the U'wa people, where one of the members of the community gave birth to two children and the community decided to abandon the babies because they were born in white people's land and therefore they contaminated the community. The indigenous tradition was that Mother Nature would take care of them, and the community left them to die. The Court saw this as a clear case wherein the individual's rights needed protection from the state (Decision To30/2000). 


\section{THE CONSERVATIVE COURT}

The Court has adopted a less activist stance in its review of cases regarding indigenous peoples after 2001. This is so mainly because of the criticism that existed against previous justices as too liberal and too activists. The Court assumed an approach that wanted to bring about more stability with the doctrines already established. In decisions C418/2002 and C891/2002 the Court gave the national government the power to limit indigenous rights in cases where mining exploitation was involved. Interesting enough, the Court considered that it was enough for the government to send the drafts of the bills to the indigenous communities to fulfill the requirement of consultations, and that it was unnecessary to get the agreement of the indigenous communities. In one decision about the conflict between indigenous rights and freedom of religion, the Court followed the past doctrine established in decision SU510/1997 (Decision T1022/2001).

There is a doctrine that is consolidated in terms of indigenous rights. In the last years the Court has stressed the importance of the right to be consulted and because of the lack of consultations with indigenous peoples, the Court has found several laws to be against the 1991 Constitution (Constitutional Decisions C030/2008 and $\mathrm{C} 175 / 2009)$. In a very recent decision (auto 004/2009), the Court analyzed the situation of indigenous peoples in Colombia and has found that forced displacement has affected not only their right as individuals, but more important their rights as a collective subject and their very existence as a people (ONIC, 2009).

In spite of the importance of the Court's decisions, the fact is that indigenous peoples are still victims of persecutions and attacks from the state and armed actors. Facing these attacks they have combined new and old forms of resistance. Indigenous guards, indigenous mingas, recovery of lands, strategic litigation, all of them are part of the strategies Indigenous Peoples use to protect their rights.

The Court decided constitutional cases and social mobilization became legal mobilization. The strategy of taking lands or of taking measures of force that 
showed the power of the movement were changed by the strategy of having legal teams defending constitutional cases and having the Court declare what the indigenous rights were. Public litigation became important thanks to the acción de tutela and the acción de constitucionalidad, two legal remedies that brought about the idea that the end of any political and social confrontation was the declaration of a right by the Constitutional Court. The struggle for rights was changed in that way for a struggle for the law. The performance of the Court and the fact that litigation became central in the activities of social movements opened the door for a myth of rights similar to the one presented in the United States by Stuart Scheingold. He defines it in the following way:

"Legal frames of reference tunnel the vision of both activists and analysts leading to an oversimplified approach to a complex social process -an approach that grossly exaggerates the role that lawyers and litigation can play in a strategy for change. The assumption is that litigation can evoke a declaration of rights from Courts; that it can, further, be used to assure the realization of these rights; and, finally, that realization is tantamount to meaningful change. The myth of rights is, in other words, premised on a direct linking of litigation, rights, and remedies with social change (Scheingold, 1974: 5)."

Scheingold finds the myth of rights flawed because it does not take into account that rights, remedies, and litigation depend on resources and effective public policies. Instead of a myth of rights he proposed a politics of rights, that is, one that recognizes the need of effective policies as a result of litigations. Scheingold presents it in the following way: "The political approach thus prompts us to approach rights as skeptics. Instead of thinking of judicially asserted rights as accomplished social facts or as moral imperatives, they must be thought of, on the one hand, as authoritatively articulated goals of public policy and, on the other, as political resources of unknown value in the hands of those who want to alter the course of public policy" (Scheingold, 1974: 6).

In Colombia, social movements had a change in the way they perceived politics after the 1991 Constitution. Social mobilization, armed struggle, 
and a clear distrust in the law and the state were the way social movements understood their mobilization during the 1970s and the 1980s (Múnera, 1998). But after 1991, the Constitutional Court framed rights and the law in such a way that became attractive for social movements. Social mobilization was replaced by legal mobilization. In the case of the indigenous movement, marches and the taking of lands saw a reduction and an increase in the activities before the Courts, where initially they were treated as minorities and slowly as a people. However, the Court cases did not bring about a change in the policies or a transformation in the model of development. Quite the contrary, the recognition of indigenous rights brought about a process of litigation that demobilized the movements; the fight for constitutional cases became the fight par excellence (Vasco, 2002).

\section{CONCLUSION}

Law as language became important in the process of indigenous resistance, as the cases of indigenous intellectual and activist Manuel Quintín Lame and indigenous organization CRIC show. But the limits of law are shown in the process followed by CRIC and the guerrilla movement Movimiento Armado Manuel Quintin Lame MAMQL. Law framed indigenous peoples' political claims, and with that frame they were able to make their demands to the Colombian government. They used strategic litigation in order to obtain from the Courts the recognition of their rights. By appealing to law, social movements, and in particular the indigenous movement, forgot other ways of mobilization. The struggle for rights became a struggle for the law. Law framed social movements, but the frame within which the cases were decided included indigenous peoples as excluded, or as Maria Emma Wills has shown for women's rights, law promoted inclusion without representation (Wills, 2007).

Charles R. Hale and Rosamel Millamán in their analysis of the politics of identity in Guatemala used Silvia Rivera Cusicanquy's concept of the 
permitted Indian (el indio permitido), in order to explain neoliberal multiculturalism and the way indigenous peoples' resistance is responded from the state. Hale presents it in the following way: "The core of neoliberalism's cultural project is not radical individualism, but the creation of subjects who govern themselves in accordance with the logic of globalized capital. The pluralism implicit in this principle -subjects can be individuals, communities or ethnic groups- cuts against the grain of mestizo nationalism, and defuses the once-powerful distinction between the forward-looking mestizo and the backward Indian. Governance now takes place instead through the distinction -to echo a World Bank dictum- between good ethnicity, which builds social capital, and "dysfunctional" ethnicity, which incites conflict" (Hale, 2004: 18).

The 1991 Constitution introduced the idea of cultural rights and indigenous rights, but the Constitutional Court solved the tension between universalism and contextualism by privileging a universal idea of human rights, constituting the field wherein indigenous peoples would be permitted. The tension between class and ethnicity simply fell into oblivion.

My study has shown the long history of the constitution of what can be labeled as the permitted subaltern. Neoliberal multiculturalism, as the one introduced in the 1991 Constitution, demobilizes social movements because it presents its rights as legal rights, that is, as rights that can only be recognized in a Court of law. Old forms of resistance, like the taking of lands, guerrilla warfare, active social mobilization, are part of the other that has to be excluded, that is, those are actions of the non-permitted Indian. A liberal politics of recognition does not mean liberation, but only recognition that indigenous peoples exist as a group and that they need to be included in the imagined community. But recognition is not social equality or the elimination of colonial structures and colonial mentalities. As Milton Fisk has held, "the cultural view of recognition stays within the bounds of neoliberalism. The cultural view keeps recognition and respect for some who have very little from leading to a violation of the freedom of yet others who have much. It does this by refusing to call for a redistribution of the assets of those who have much. Put in structural terms, the cultural view 
does not challenge the market. However, the social view of recognition does not counter pose recognition and equality; instead, it makes equality a vital part of recognition" (Fisk, 2005: 27).

Though the 1990 s were for indigenous peoples a decade of demobilization, and in a way a success in terms of neoliberal multiculturalism, after ten years of the 1991 Constitution indigenous peoples have realized the need of appealing to other forms of mobilization besides legal mobilization before the Courts. As McNeish writes, in his analysis of indigenous mobilization in Guatemala and Bolivia, "[r]ather than appearing as passive victims of those who come to steal their natural resources, marginalized sectors have been confronting perceived threats in an active and innovative manner" (McNeish, 2008: 48).

To say it in the indigenous peoples' own words:

"...no caben planteamientos de acciones indigenistas que no busquen la ruptura radical de la situación actual: liquidación de las relaciones coloniales externas e internas, quebrantamiento del sistema clasista de explotación y de dominación étnica, desplazamiento del poder económico y político de una minoría oligárquica a las masas mayoritarias, creación de un estado verdaderamente multiétnico en el cual cada etnia tenga derecho a la autogestión y a la libre elección de alternativas sociales y culturales (CRIC, 1981:135)." 


\section{REFERENCES}

- Alvarez, Sonia, Arturo Escobar \& Evelina Dagnino. 2001. Política Cultural y Cultura Política. Una nueva mirada sobre los movimientos sociales latinoamericanos. Bogotá: Taurus/ICANH.

- Alvarez, Sonia \& Arturo Escobar. 1992. The Making of Social Movements in Latin America. Identity, Strategy and Democracy. Boulder/San Francisco/ Oxford: Westview Press.

- Anaya, James. 2009. Elementos sobre la Situación de Derechos Civiles y Políticos de los Pueblos Indígenas en Colombia. Visita a Colombia Relator Especial de Naciones Unidas sobre la situación de los Derechos Humanos y las Libertades Fundamentales de los Pueblos Indígenas.

- Anderson, Benedict. 2003. Imagined communities. London: Verso.

- Assies, Willem et al. eds. 1998. The Challenge of Diversity: Indigenous Peoples and Reform of the State in Latin America. Amsterdam: Thela Thesis.

- Barona Becerra, Guido. 1993. Legitimidad y Sujeción. Los Paradigmas de la "Invención" de América. Bogotá: Instituto Colombiano de Cultura.

- Benavides Vanegas, Farid Samir. 2009. A Tutelazo Limpio. A story of the struggle for identity and rights in Colombia Saarbrucken: VDM Verlag.

- Bengoa, José. 2000. La Emergencia Indígena en America Latina. Santiago: Fondo de Cultura Económica.

- Bernal Heredia, Sandra Vanessa. 2009. The Third Nation: A project of national identity formation in Bolivia. Master Thesis. Univesity of Miami.

- Bickel, Alexander. 1962. The least dangerous branch; the Supreme Court at the bar of politics. Indianapolis: Bobbs Merril.

- Bonilla, Daniel. 2006. La Constitución Multicultural. Bogota: Universidad de los Andes.

- Bonilla, Victor D. 1972. Servants of God or masters of men? the story of a Capuchin mission in Amazonia. Harmondsworth, Penguin.

- Brysk, Alison. 2007. Globalización y Pueblos Indígenas: el rol de la sociedad civil internacional en el siglo XXI. In Salvador Marti i Puig, ed. 
Pueblos Indígenas y Política en América Latina. El reconocimiento de sus derechos y el impacto de sus demandas a inicios del siglo XXI. Barcelona: CIDOB.

- de la Cadena, Marisol. ¿Son los mestizos híbridos? Las políticas conceptuales de las identidades andinas. Universitas Humanística No. 61 Enero/Junio 2006. Pág. 51-84.

- Campos Chicangana, Ary. 2003. Montoneras. Montoneras, deserciones e insubordinaciones. Yanaconas y Paeces en la Guerra de los Mil Dias. Cali: Archivo Histórico de Cali.

- Castrillón Arboleda, Diego. 1973. El Indio Quintín Lame. Bogotá: Tercer Mundo Editores.

- Consejo Regional Indígena del Cauca. 1981. Diez años de lucha. Historia y Documentación. Unidad, tierra, y cultura. Serie Controversia No. 91-92. Bogotá: CINEP.

- Coronado, Jorge. 2009. The Andes Imagined: Indigenismo, Society and Modernity. Pittsburgh: University of Pittsburgh Press.

- Díaz Reina, Juan Camilo. 2008. La eficacia de la resistencia civil de los pueblos indígenas del Cauca. Tesis de Grado Facultad de Ciencia Política y Relaciones Internacionales. Bogotá: Pontificia Universidad Javeriana.

- Dugas, John (comp). 1993. La Constitución de 1991. Un Pacto Político Viable? Bogotá: Universidad de los Andes.

- Espinosa, Mónica. 2007. Manuel Quintín Lame. In Santiago Castro Gómez, Alberto Flórez Malagón, Guillermo Hoyos Vásquez, Carmen Millán de Benavides, eds. Pensamiento Colombiano del siglo XX. Bogotá: Instituto Pensar.

- Espinosa, Mónica. 2004. Of visions and sorrows: Manuel Quintín Lame’s Indian thought and the violences of Colombia. Unpublished Dissertation. Amherst: University of Massachusetts.

- Fisk, Milton. 2005. Multiculturalism and Neoliberalism. Praxis Filosòfica, Nueva Serie No. 21.

- Gorriti, Gustavo. 1990. Sendero: historia de la guerra milenaria en el Perú. Lima: Editorial Apoyo.

- Hale, Charles R. 2004. Rethinking Indigenous Politics in the Era of the Indio Permitido. NACLA Report on the Americas. 
- Hernández Delgado, Esperanza. 2006. La Resistencia Civil de los Indígenas del Cauca. Papel Político Vol. 11 No. 1. Págs. 177-220.

- Houghton, Juan Carlos and William Villa. 2005. Violencia Política contra los pueblos indígenas en Colombia 1974-2004. Bogotá: CECOIN.

- Houghton, Juan Carlos. 2009. Pueblos Indígenas, Izquierda y Resistencia en Colombia. In HYPERLINK "http://www.tinku.org”www.tinku.org. Última visita 30 de septiembre de 2009.

- Kalman, Laura. 1996. The strange career of legal liberalism. New Haven: Yale.

- Laguado Duca, Arturo Claudio. 2004. Pragmatismo y Voluntad. La idea de Nación de las élites en Colombia y Argentina 1880-1910. Bogotá: Universidad Nacional de Colombia.

- Laurent, Virginia. 2005. Comunidades Indígenas, Espacios Políticos y Movilizaciones Electorales en Colombia 1990-1998. Motivaciones, campos de acción e impactos. Bogotá: ICANH-IFCA.

- Laurent, Virginia. 1997. Población Indígena y Participación Política en Colombia. Las elecciones de 1994. Análisis Político 31.

- Mayburi-Lewis, David. 2002. The politics of ethnicity: Indigenous peoples in Latin American states. Cambridge: The David Rockefeller Center Series on Latin American Studies, Harvard University.

- McNeish, John Andrew. 2008. Beyond the permitted Indian? Bolivia and Guatemala in an age of neoliberal developmentalism. Latin American and Caribbean Ethnic Studies vol. 3:1. Págs. 33-59.

- Múnera, Alfonso. 2005. Fronteras Imaginadas. La construcción de las razas y de la geografía en el siglo XIX colombiano. Bogota: Editorial Planeta.

- Múnera Ruiz, Leopoldo. 1998. Rupturas y Continuidades. Poder y Movimiento Popular (Colombia, 1968 - 1988). Bogota: Universidad Nacional de Colombia.

- Nash Rojas, Claudio. 2004. Los derechos humanos de los indígenas en la jurisprudencia de la Corte Interamericana de Derechos Humanos. In José Aylwin, ed. Derechos Humanos y Pueblos Indígenas: Tendencias internacionales y Contexto Chileno. Santiago: IWGIA. 
- Organización Nacional Indígena ONIC. 2009. Estado de los Derechos Humanos y Colectivos de los Pueblos Indígenas de Colombia; Etnicidio, Limpieza Étnica y Destierrro. Bogotá: ONIC.

- Otero, Gerardo. 2003. The Indian Question in Latin America. Class, State, and Ethnic Identity Construction. Latin American Research Review, vol. 38 No. 1.

- Peñaranda, Ricardo. ed. 1991. Pasado y Presente de la Violencia en Colombia. Bogotá, CEEC.

- Rappaport, Joanne. 2005. Intercultural utopias: public intellectuals, cultural experimentation, and ethnic pluralism in Colombia. Durham: Duke University Press.

- Restrepo Amariles, David. 2009. A Dialogical Approach to Indigenous Lands Protection: Colombian Lessons in a Global Perspective. Silesian Journal of Legal Studies No. 1.

- Rojas, Cristina. 2002. Civilization and Violence: Regimes ofRepresentation in Nineteenth Century Colombia. Minneapolis: University of Minnesota Press.

- Romero Loaiza, Fernando. 2005. Manuel Quintín Lame Chantre. El indígena ilustrado, el pensador indigenista. Pereira: Editorial Papiro.

- Sánchez, Francisco. 2007. Ecuador: El Indio como problema. In Salvador Marti i Puig, ed. Pueblos Indígenas y Política en América Latina. El reconocimiento de sus derechos y el impacto de sus demandas a inicios del siglo XXI. Barcelona: CIDOB.

- Sánchez, Gonzalo \& Ricardo Peñaranda, comps. 2007. Pasado y Presente de la Violencia en Colombia. Bogotá: La Carreta Histórica.

- Sánchez, Gonzalo. 1991. Guerra y Política en la Sociedad Colombiana. Bogotá: El Ancora editores.

- Scheingold, Stuart. 1974. The Politics of Rights: lawyers, public policy, and political change. New Haven: Yale University Press.

- Toro, Beatriz. 1994. La Revolución o los hijos. Mujeres y Guerrilla. EPL, M-19, Quintín Lame, PRT. Unpublished thesis. Bogotá: Universidad de los Andes/Departamento de Antropología.

- Ulloa, Astrid. 2004. La construcción del nativo ecológico. Bogotá: Instituto Colombiano de Antropología. 
- Uribe, Maria Tila. 2007. Los años escondidos. Sueños y Rebeldías en la Década del Veinte. Bogotá: Antropos.

- Vasco, Luis Guillermo. 2002. Entre selva y páramo. Viviendo y pensando la lucha india. Bogotá: ICANH.

- Valencia, León. ed. 2007. Parapolítica: la ruta de la expansión paramilitar y los acuerdos políticos. Bogotá: Intermedio/Corporación Arco Iris.

- Van Cott, Donna Lee. 2008. Latin America's Indigenous Peoples. Journal of Democracy, vol. 18, No. 4.

- Van Cott, Donna Lee. 2000. The friendly liquidation of the past. The politics of Diversitity in Latin America. Pittsburgh: University of Pitssburgh Press.

- Wills, María Emma. 2007. Inclusión sin Representación. La irrupción política de las mujeres en Colombia 1970-200o. Bogotá: Editorial Norma.

- Yashar, Deborah J. 2004. Contesting citizenship in Latin America. The rise of Indigenous Movements and the Postliberal Challenge. Cambridge: Cambridge University Press.

- Zamosc, Leon. 2007. The Indian Movement and Political Democracy in Ecuador. Latin American Politics and Society 49:3. 


\section{ICIP WORKING PAPERS - SUBMISSION GUIDELINES}

1. International Catalan Institution for Peace (ICIP):

The principle purpose of the ICIP is to promote a culture of peace in Catalonia as well as throughout the world, to endorse peaceful solutions and conflict resolutions and to endow Catalonia with an active role as an agent of peace and peace research.

2. Objectives of the Publication:

The ICIP wants to create an open forum on topics related to peace, conflict and security. It aims to open up debate and discussion on both theoretical and contemporary issues associated with the pursuit and maintenance of peace in our world. It strives to connect an eclectic group of voices including career academics, PhD students, NGO representatives, institutional representatives, and field workers and field writers to celebrate groundbreaking and constructive approaches to peace and conflict resolution.

3. Scope of the Publication (List of Themes):

The ICIP is interested in works related to peace, conflict and security research. It aims to provide an innovative and pluralist insight on topics of methodology of peace research, the history and development of peace research, peace education, peace-keeping and peace-creating, conflict resolution, human security, human rights, global security, environmental security, development studies related to peace and security, international law related to peace, democracy, justice and equality, disarmament, gender, identity and ethics related to peace, science and technology associated with peace and security.

\section{Audience:}

The ICP aims to provide accessible, valuable and well-researched material for all those interested in the promotion of peace. Our audience includes 
fellow academics and researchers, student of peace ands security, field workers, institutional and governmental representatives as well as the general public.

5. The review process:

ICIP WP is a peer reviewed publication. Submissions should be sent directly to the series editor (recerca.icip@gencat.cat), who will check whether the paper meets the formal and general criteria for a working paper and will commission a review.

6. Who may submit working papers:

a. The main criterion for the submission of Working Papers is whether this text could be submitted to a good academic journal.

b. ICIP staff and other fellows and visitors affiliated with the ICIP are expected to submit a working paper related to their research while at the ICIP.

7. Submission System:

All submissions can be made to the ICIP, e-mail address recerca.icip@ gencat.cat with "Working Papers - submission" in the subject line.

For a complete version of the ICIP WP submission guidelines, please visit the publications section of the website www.icip.cat.

Una versió completa i en català d'aquests criteris de sumbissió de texts la trobareu a la secció de publicacions del lloc web www.icip.cat.

Una versión completa y en castellano de estos criterios de sumisión de textos se encuentra en el apartado de publicaciones de la página web www.icip.cat. 


\section{NEXT NUMBERS OF THE ICIP WORKING PAPERS SERIES}

Working Paper 9: Lecciones de la paz en Aceh: descentralización administrativa y libertad política como estrategia de pacificación en Aceh, by Javier Gil Pérez

\section{EDITED NUMBERS OF THE ICIP WORKING PAPERS SERIES}

Working Paper 7: A Critical Application of Securitization Theory: Overcoming the Normative Dilemma of Writing Security, by Catherine Charrett.

Working Paper 6: Bringing actors and violent conflict into forced migration literature. A model of the decision to return, by Inmaculada Serrano.

Working Paper 5: The Quest for Regulating the Global Diamond Trade, by Franziska Bieri.

Working Paper 4: Hezbollah's identities and their relevance for cultural and religious IR, by Pol Morillas Bassedas.

Working Paper 3: Eleccions pacífiques a Costa d'Ivori a finals del 2009? Avenços i obstacles de la construcció de pau al país ivorià, by Albert Caramés.

Working Paper 2: Prohibició de submissió a nou judici - regla del ne bis in idem - en el sistema interamericà de drets humans i en el dret comparat, by Priscila Akemi Beltrame.

Working Paper 1: Conflict prevention and descentralized governance, by Rafael Grasa and Arnau Gutiérrez Camps. 
INTERNATIONAL

CATALAN

INSTITUTE

\section{FOR PEACE}

GRAN VIA, 658 BAIX. 08010 BARCELONA (SPAIN)

T. +34935544270| F. +34935544280

ICIP@GENCAT.CAT | WWW.ICIP.CAT 